\title{
Respostas antioxidativas, fisiológicas e produtiva de arroz cultivado sob deficiência hídrica e adubação silicatada
}

\section{Antioxidative responses, physiological and productive of rice grown under water deficit and silicon fertilization}

\author{
Adriana Lima Moro $^{1 *}$; Fernando Broetto ${ }^{2}$; Edemar Moro ${ }^{3}$
}

\begin{abstract}
Resumo
O silício é um nutriente que pode proporcionar melhor desenvolvimento às plantas de arroz cultivadas em ambientes com deficiência hídrica. Este elemento diminui as perdas de água por transpiração, aumenta a taxa fotossintética e atua como ativador do sistema de defesa enzimático. O objetivo deste trabalho foi analisar o efeito do silício em dois cultivares de arroz (Curinga e o IAC 202) submetidos à deficiência hídrica, sobre os parâmetros enzimáticos, fisiológicos e produtivo. Foram utilizados quatro tensões de água no solo $(-10,-30,-50$ e $-70 \mathrm{kPa})$ combinadas com duas formas de correção da saturação do solo (ausência e presença de silício). Foram avaliados a atividade enzimática de Superóxido dismutase, Catalase e Ascorbato Peroxidase, a taxa de assimilação de $\mathrm{CO}_{2}$ e a produção de grãos. O delineamento experimental foi em blocos casualizado em esquema fatorial 4 x 2 , com quatro repetições, sendo as médias comparadas pelo teste de Tukey $(\mathrm{p}<0,05)$. A atividade enzimática aumentou com a aplicação de silício mesmo em condições de deficiência hídrica mais intensa. A taxa de assimilação de $\mathrm{CO}_{2} \mathrm{e}$ a produção de grãos também aumentaram com a adição de silício. A aplicação de silício em ambos cultivares de arroz ameniza os efeitos do estresse ocasionado pela deficiência hídrica.
\end{abstract}

Palavras-chave: SOD, assimilação de $\mathrm{CO}_{2}$, estresse

\begin{abstract}
Silicon is a nutrient that can provide better development of rice plants grown in environments with water deficit. This element reduces water loss by transpiration, increases photosynthetic rate and acts as an activator of the enzyme defense system. The purpose of this research was analyse the effect of silicon in two rice cultivars (Curinga and IAC 202) submitted to water deficit under the enzymatic parameters, physiological and productive. We used four strains of soil water $(-10,-30,-50$ and -70 $\mathrm{kPa}$ ) combined with two ways of correcting the soil saturation (absence and presence of silicon). We measured the enzymatic activity of Superoxide dismutase, catalase and ascorbate peroxidase, the rate of $\mathrm{CO}_{2}$ assimilation and yield. The experimental design was randomized in blocks $4 \times 2$ factorial with four replications, and the means compared by Tukey test $(\mathrm{p}<0.05)$. The enzyme activity increased with the application of silicon even in intense water deficit. The $\mathrm{CO}_{2}$ assimilation rate and also grain yield increased with the addition of silicon. The application of silicone on both cultivars alleviate the effects of stress caused by lack of water.
\end{abstract}

Key words: $\mathrm{SOD}, \mathrm{CO}_{2}$ assimilation, stress

\footnotetext{
${ }^{1}$ Bióloga, Prof $^{\mathrm{a}}$ Dr $^{\mathrm{a}}$, Universidade do Oeste Paulista, UNOESTE, Faculdade de Ciências Agrárias, Presidente Prudente, SP. E-mail: adrianamoro@unoeste.br

2 Eng $^{\circ}$ Agr , Prof. Dr. Adjunto, Dept ${ }^{\circ}$ de Química e Bioquímica, Universidade Estadual Paulista "Júlio de Mesquita Filho", UNESP, Instituto de Biociências, Botucatu, SP. Bolsista do CNPq. E-mail: broetto@ibb.unesp.br

3 Eng $^{\circ}$ Agr $^{\circ}$, Prof. Dr., Universidade do Oeste Paulista, UNOESTE, Faculdade de Ciências Agrárias, Presidente Prudente, SP. E-mail: edemar@unoeste.br

* Autor para correspondência
} 


\section{Introdução}

O arroz é uma das culturas mais antigas cultivadas no mundo, de origem tropical adaptada a sistemas de cultivo alagado e de sequeiro. $\mathrm{O}$ arroz é um dos cereais de maior importância em muitos países em desenvolvimento, principalmente na Ásia e Oceania, onde vivem $70 \%$ da população total dos países em desenvolvimento e cerca de dois terços da população subnutrida mundial (LOPES, et al., 2013). A importância da cultura no Brasil aumenta com o crescimento da população (SOARES et al., 2014).

São considerados dois grandes ecossistemas para a cultura do arroz, o de várzea, irrigado por inundação controlada, e o de terras altas, com ou sem irrigação suplementar por aspersão (KLUTHCOUSKI; PINHEIRO, 2003). Os cultivares de terras altas diferenciam-se dos irrigados principalmente por apresentarem maior tolerância a seca. Para isso, possuem um sistema radicular extenso para explorar a umidade do solo em maior profundidade, porte baixo e folhas eretas (MAUAD; CRUSCIOL; GRASSI FILHO, 2011).

Entre as gramíneas, o arroz possui grande capacidade de absorção de $\mathrm{Si}$, sendo considerada uma planta acumuladora de silício, o qual é translocado, acompanhando o fluxo transpiratório, acumulandose na parte aérea (OLIVEIRA; KORNDÖRFER; PEREIRA, 2007). O Si promove maior resistência à infecção de fitopatógenos, retarda a senescência das folhas, melhora a arquitetura e a taxa fotossintética das plantas, reduz a transpiração e aumenta a tolerância ao déficit hídrico (PULZ, 2007).

Estresses ambientais têm um impacto direto sobre o aparato fotossintético, principalmente por perturbar todos os componentes da fotossíntese, incluindo o transporte de elétrons pelo tilacóide e o controle estomático, ocasionando peroxidação de lipídios (ANJUM et al., 2011).

A deficiência hídrica é a principal responsável pela baixa produtividade e instabilidade de produção do arroz de sequeiro. Condições de seca afetam os processos fotossintéticos e bioquímicos das plantas, inibindo assim o crescimento foliar ao limitar a disponibilidade de água dos tecidos fontes. A fotossíntese é reduzida de três maneiras: pela redução da área foliar disponível para interceptar a radiação solar, pela redução da difusão do $\mathrm{CO}_{2}$ para dentro da folha e pela redução da habilidade dos cloroplastos para fixar o $\mathrm{CO}_{2}$ que neles penetra (JONES; OSMOND, 1973), diminuindo o crescimento e a produtividade da planta (PEAK, 2004).

Respostas fotossintéticas à seca são altamente complexas, ocorrendo em diferentes locais da célula/ folha e em diferentes escalas de tempo em relação ao desenvolvimento da planta. A intensidade, duração e taxa de progressão do estresse poderá influenciar fatores que irão ditar se os processos de mitigação associadas com aclimatação ocorrerá ou não (CHAVES; FLEXAS; PINHEIRO, 2009).

As plantas sofrem alterações no seu metabolismo quando mantidas sob condições ambientais adversas. As enzimas e compostos orgânicos formados em situação de estresse ambiental, podem ser determinado e respondem também de forma específica conforme o envolvimento de reações metabólicas que se façam necessárias.

Espécies reativas de oxigênio (ROS) são gerados como subprodutos de várias reações metabólicas. Sendo prontamente difundido e altamente reativo, as ROS podem afetar uma variedade de niveis celulares. Portanto, as ROS podem agir como moléculas sinalizadoras que regulam muitos processos celulares, como o crescimento, desenvolvimento e respostas das plantas ao estresse (GARA et al., 2010). São vários tipos de ROS como os radicais superóxido $\left(\mathrm{O}_{2}^{-}\right)$, peróxido de hidrogênio $\left(\mathrm{H}_{2} \mathrm{O}_{2}\right)$ e radicais hidroxila $(\mathrm{OH})$, que danificam as plantas pela oxidação dos pigmentos fotossintéticos e destruição dos lipídios, proteínas e ácidos nucléicos (REDDY; CHAITANYA; VIVEKANANDAN, 2004). 
As plantas são dotadas com um sistema efetivo para controlar a ação deletéria destes radicais. Em várias espécies vegetais observou-se uma expressão da atividade de algumas enzimas como a superóxido dismutase (SOD), ascorbato peroxidase (APx), catalase (CAT). A SOD é altamente eficiente e está presente em vários compartimentos subcelulares, está subdivida por seus cofatores: Fe-SOD cloroplastos e mitocondrias, Mn-SOD mitocôndria e peroxissomos e $\mathrm{Cu} / \mathrm{Zn}$-SOD cloroplasto e citosol (GILL; TUJELA, 2010). A isoforma da APx está envolvida no balanço de $\mathrm{H}_{2} \mathrm{O}_{2}$ em cloroplastos (CARVALHO et al., 2014). A APx está envolvida na limpeza de $\mathrm{H}_{2} \mathrm{O}_{2}$ no cilco água-água. A enzima Catalase é capaz de converter aproximadamente 6 milhões de $\mathrm{H}_{2} \mathrm{O}_{2}$ em $\mathrm{H}_{2} \mathrm{O}$ e $\mathrm{O}_{2}$ por minuto, muitos desses $\mathrm{H}_{2} \mathrm{O}_{2}$ são gerado nos peroxissomos (GILL; TUJELA, 2010).

A acumulação de silício nos estomas propicia a formação de uma dupla camada de sílica cuticular, ocasionando redução da transpiração fazendo com que a exigência de água pelas plantas seja menor, aumentando a eficiência no uso da água pelo vegetal e a taxa fotossintética (NWUGO; HUERTA, 2008). Diferentes concentrações de silício promove a atividade de enzimas antioxidantes como a superóxido dismutase (SOD), catalase (CAT) e ascorbato peróxidase (APx) (MOLDES et al., 2006).

O objetivo deste trabalho foi analisar o efeito do silício, em dois cultivares de arroz (Curinga e o IAC 202) submetidos à deficiência hídrica, sobre os parâmetros enzimáticos, fisiológicos e produtivo.

\section{Material e Métodos}

Foram conduzidos dois experimentos em ambiente protegido, no primeiro utilizou-se o cultivar de arroz Curinga, moderno e ciclo semi precoce, de boa produtividade e resistência a seca. No segundo experimento, foi utilizado o cultivar o IAC 202, moderno de ciclo médio e bom rendimento de grãos inteiros. Foram utilizadas quatro plantas por vaso, sendo duas utilizadas para análises destrutivas e duas para análise de produção de grãos.

O delineamento experimental foi em blocos casualizados em esquema fatorial $4 \times 2$, com 4 repetiçõesAs análises foram realizadas durante o ciclo fenológico da planta (perfilhamento, emborrachamento, florescimento e enchimento de grãos). Os tratamentos foram constituídos por quatro tensões de água no solo $(-10,-30,-50$ e -70 $\mathrm{kPa}$ ) combinadas com duas formas de correção da saturação de bases do solo (ausência e presença de silício). Os corretivos utilizados foram calcário dolomítico e silicato de cálcio e magnésio.

O solo utilizado foi um Latossolo Vermelho (EMBRAPA, 1997), coletado na Fazenda Experimental Lageado, cuja as características física são: $200 \mathrm{~g} \mathrm{~kg}^{-1}$ de argila, $640 \mathrm{~g} \mathrm{~kg}^{-1}, 160 \mathrm{~g} \mathrm{~kg}^{-1} \mathrm{de}$ silte. Após a caracterização química, foi adicionado ao solo em lotes separado o calcário dolomítico e o silicato de cálcio e magnésio. Após a aplicação dos corretivos e fertilizantes o solo foi incubado durante 30 dias, com umidade na capacidade máxima de retenção de água. Após a incubação, foi realizada novamente a caracterização química do solo (Tabela 1) de acordo com a metodologia proposta por Raij et al. (2001). Foram utilizados vasos com capacidade para 17 litros de solo. 
Tabela 1. Atributos químicos do solo antes e após a incubação com calcário e silicato de cálcio e magnésio.

\begin{tabular}{lccccccccccc}
\hline $\begin{array}{c}\text { Corretivos } \\
\text { de acidez }\end{array}$ & $\mathbf{S i}$ & $\mathbf{p H}$ & $\mathbf{M . O}$ & $\mathbf{P}(\mathbf{r e s i n a})$ & $\mathbf{H}+\mathbf{A l}$ & $\mathbf{K}$ & $\mathbf{C a}$ & $\mathbf{M g}$ & $\mathbf{S B}$ & $\mathbf{C T C}$ & $\mathbf{V}$ \\
\hline $\mathrm{g} \mathrm{dm}^{-3}$ & $\mathrm{CaCl}_{2}$ & $\mathrm{~g} \mathrm{dm}^{-3}$ & $\mathrm{mg} \mathrm{dm}^{-3}$ & & ------------ & $\mathrm{mmol}_{c} \mathrm{dm}^{-3}------------$ & $\%$ \\
\hline Sem correção & 4 & 4,0 & 14 & 7 & 73 & 0,4 & 5 & 2 & 7,4 & 80 & 34 \\
Calcário & 6 & 4,6 & 16 & 44 & 51 & 3,5 & 34 & 11 & 48 & 99 & 49 \\
\hline Silicato & 8 & 4,6 & 20 & 50 & 52 & 3,4 & 27 & 19 & 49 & 101 & 49 \\
\hline
\end{tabular}

*Si: silício, pH: potencial de hidrogênio, M.O.: matéria orgânica, P: fósforo, H: hidrogênio, Al: alumínio, K: potássio, Ca: cálcio, Mg: magnésio, SB: soma de base, CTC: capacidade de troca catiônica, V: saturação de base.

Fonte: Elaboração dos autores.

Os tratamentos com restrição hídrica foram iniciados aos 30 dias após a emergência e mantidos até a colheita. As lâminas de água utilizadas constaram de um tratamento controle (-10 $\mathrm{kPa})$ e deficiência hídrica leve, moderada e severa, que corresponderam a $-30,-50$ e -70 $\mathrm{kPa}$, respectivamente. Os volumes de água para cada potencial hídrico foram determinados pela curva da capacidade de retenção de água do solo. A metodologia utilizada foi a de placas de pressão recomendada por Richards (1949) e Topp et al. (1993). A tensão de água no solo (Tabela 2) foi controlada mediante pesagem diária de todos os vasos em todos os tratamentos, para o cálculo do volume de reposição da água evapotranspirada.

Tabela 2. Relações entre teores de água e potenciais de água do solo (base massa seca) utilizados no experimento.

\begin{tabular}{|c|c|c|c|c|c|c|}
\hline \multicolumn{7}{|c|}{ Potencial hídrico solo (Kpa) } \\
\hline Saturado & -10 & -30 & -50 & -70 & -100 & -150 \\
\hline \multicolumn{7}{|c|}{ Teor de água \% } \\
\hline 24 & 15,0 & 13,0 & 12,0 & 11,0 & 10,3 & 8,3 \\
\hline
\end{tabular}

Fonte: Elaboração dos autores.

As análises bioquímicas foram realizadas em quatro coletas no decorrer do ciclo fenológico (perfilhamento, emborrachamento, florescimento e enchimento de grãos) das plantas. As folhas expandidas foram coletadas da região mediana das plantas, acondicionadas em frascos do tipo Falcon e imediatamente imersas em nitrogênio líquido para congelamento rápido. Após a coleta, as amostras foram armazenadas em Freezer a -80 ${ }^{\circ} \mathrm{C}$. O extrato para as análises enzimáticas foi obtido pela ressuspensão do material vegetal $(300 \mathrm{mg}) \mathrm{em}$ $5,0 \mathrm{~mL}$ de tampão fosfato de potássio $0.1 \mathrm{M}, \mathrm{pH}$ 7,8. Após centrifugação por 10 minutos a $5.000 \mathrm{x}$ $\mathrm{g}$, o sobrenadante foi coletado e armazenado em ultrafreezer $\mathrm{a}-80^{\circ} \mathrm{C}$.
A atividade da SOD foi determinada pela adição de $50 \mu \mathrm{L}$ do extrato enzimático bruto a $5 \mathrm{~mL}$ de meio de reação constituído de tampão-fosfato de sódio $50 \mathrm{mmol} \mathrm{L-1,} \mathrm{pH}$ 7,8, contendo metionina $13 \mathrm{mmol} \mathrm{L}-1$, azul de p-nitro tetrazólio (NBT) 75 $\mu \mathrm{mol} \mathrm{L}-1$, EDTA $0,1 \mathrm{mmol} \mathrm{L}-1$ e riboflavina $2 \mu \mathrm{mol}$ L-1. A reação foi conduzida a $25^{\circ} \mathrm{C}$, numa câmara de reação, sob iluminação de lâmpada fluorescente de $15 \mathrm{~W}$, mantida no interior de uma caixa coberta com papel-alumínio. Após 5 min de exposição à luz, a iluminação foi interrompida, e a formazana azul produzida pela fotorredução do NBT foi medida pela absorvância a $560 \mathrm{~nm}$. A absorvância a $560 \mathrm{~nm}$ de um meio de reação exatamente igual ao anterior, mas mantido no escuro por igual período, serviu de branco e foi subtraído da leitura da amostra que 
recebeu iluminação (GIANNOPOLITIS; RIES, 1977). Uma unidade de SOD foi definida como a quantidade de enzima necessária para a inibição de $50 \%$ da fotorredução do NBT.

A atividade da enzima catalase foi determinada por medição em um aparelho espectrofotômetro a um comprimento de onda de $240 \mathrm{~nm}$ pelo monitoramento da variação da absorção do peróxido de hidrogênio, conforme Peixoto et al. (1999). Para o teste, foi adicionado $50 \mu \mathrm{L}$ de extrato bruto a 950 $\mu \mathrm{L}$ de um tampão fosfato de potássio $50 \mathrm{mM}, \mathrm{pH}$ 7,0 suplementado com peróxido de hidrogênio a uma concentração final de $12,5 \mathrm{mM}$. A variação de absorção $(\Delta \mathrm{E})$ foi calculada em um intervalo de 90 $\mathrm{s}$, sendo a atividade da enzima calculada utilizandose um coeficiente de extinção molar $\varepsilon=39,4 \mathrm{mM}^{-1}$ $\mathrm{cm}^{-1}$. A atividade específica ( $\mu$ Kat $\mu \mathrm{g} \operatorname{Prot}^{-1}$ ) da catalase, levou-se em consideração a concentração de proteína solúvel no teste.

Para a análise da atividade da enzima APX, inicialmente prepara-se uma solução de trabalho contendo uma alíquota de $100 \mathrm{~mL}$ de extrato bruto com 2,9 mL de tampão fosfato de potássio $50 \mathrm{mM}, \mathrm{pH}$ 6,0 (volume final de 3,0 mL). A esta solução acrescenta-se ascorbato e peróxido de hidrogênio, em concentração final de 0.8 e 1,0 mM, respectivamente. A determinação da variação da extinção é efetuada a $290 \mathrm{~nm}$, sendo que a atividade específica da enzima ( $\mu$ Kat $\mu \mathrm{g}$ Prot $^{-1}$ ) deve ser calculada a partir de um coeficiente de extinção molar de 2,8 $\mathrm{mM} \mathrm{cm}^{-1}$ (KOSHIBA, 1993).

As coletas para medições de trocas gasosas foram realizadas durante três fases fenológicas: perfilhamento, emborrachamento e florescimento. Foi determinado a taxa liquida de assimilação de $\mathrm{CO}_{2} A$ ( $\mu \mathrm{mol} \mathrm{CO}_{2} \mathrm{~m}^{-2} \mathrm{~s}^{-1}$ ), essas medidas foram realizadas com um medidor portátil de trocas gasosas por infravermelho "Infra Red Gas Analyser - IRGA”, modelo LI-6400, LI-COR.

A produção de grãos foi obtida pela colheita das panículas de uma planta por vaso. A trilha dos grãos (das panículas) foi realizada manualmente. Os grãos passaram por um processo de limpeza para a separação da palha e das espiguetas chochas. Após esta operação, os grãos foram pesados e em seguida calculou-se a produção em gramas por planta.

Os dados foram submetidos à análise de variância, pelo teste $\mathrm{F}$, para cada cultivar estudado. A análise de regressão linear e polinomial foi realizada adotando-se o modelo de melhor ajuste pelo programa Sisvar. A confecção dos gráficos foram realizadas com o programa SigmaPlot 10.0.

\section{Resultados e Discussão}

A análise de variância (Tabela 3) demonstrou que houve efeito da aplicação de corretivo em todas as coletas para o cultivar Curinga e a partir do florescimento para o cultivar IAC 202. Os resultados da SOD para o IAC 202, mantevese constante com a adição de silício, mesmo em maiores tensões hídricas (Figura 1 E, F), a partir da fase de florescimento houve aumento da atividade da SOD com adição de silício até a tensão de -50 $\mathrm{kPa}$ (Figura $1 \mathrm{G}, \mathrm{H}$ ). Para o cultivar Curinga a atividade da SOD foi maior com adição de silício até a tensão de $-50 \mathrm{kPa}$ (Figura 1A), na segunda coleta (Figura 1B) manteve-se constante diante da intensidade da deficiência hídrica. Na fase de florescimento nas maiores tensões -50 e $-70 \mathrm{kPa}$ (Figura 1C) apresentou aumento da atividade com adição de silício, seguido de redução na próxima coleta com maiores tensões hídricas (Figura 1D). A fase de emborrachamento é sensível a estresses térmicos e hídricos e, um aumento da atividade da SOD com a aplicação de silício implica num sistema antioxidativo mais eficaz. Na fase de florescimento o cultivar IAC 202 apresentou aumento de $65 \%$ na atividade da SOD, em tensão moderada de $-30 \mathrm{kPa}$. Contudo, para o cultivar Curinga houve aumento de $54 \%$ na atividade da SOD submetido a deficiência severa de $-70 \mathrm{kPa}$. 
Figura 1. Atividade da SOD em folhas de arroz, cultivar Curinga e IAC 202 (A e E - perfilhamento, B e Femborrachamento, C e G- florescimento, D e H- enchimento de grãos), em função do manejo de água no solo e silício.

Curinga

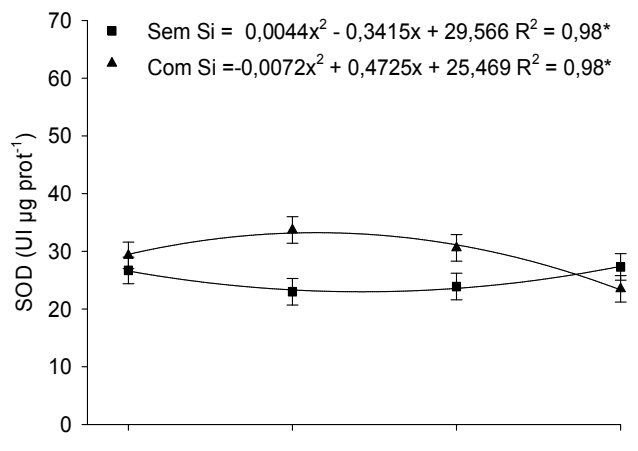

A

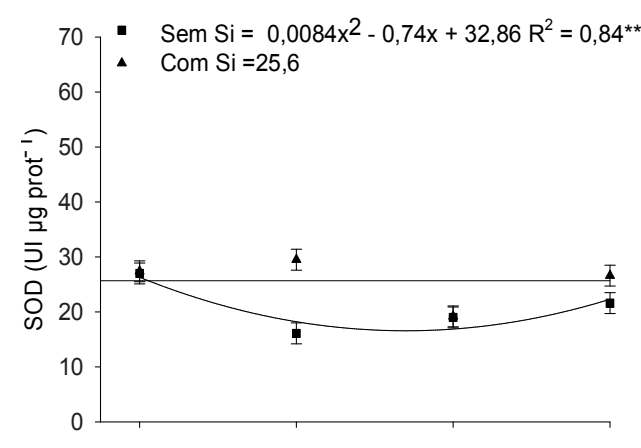

$\mathrm{B}$
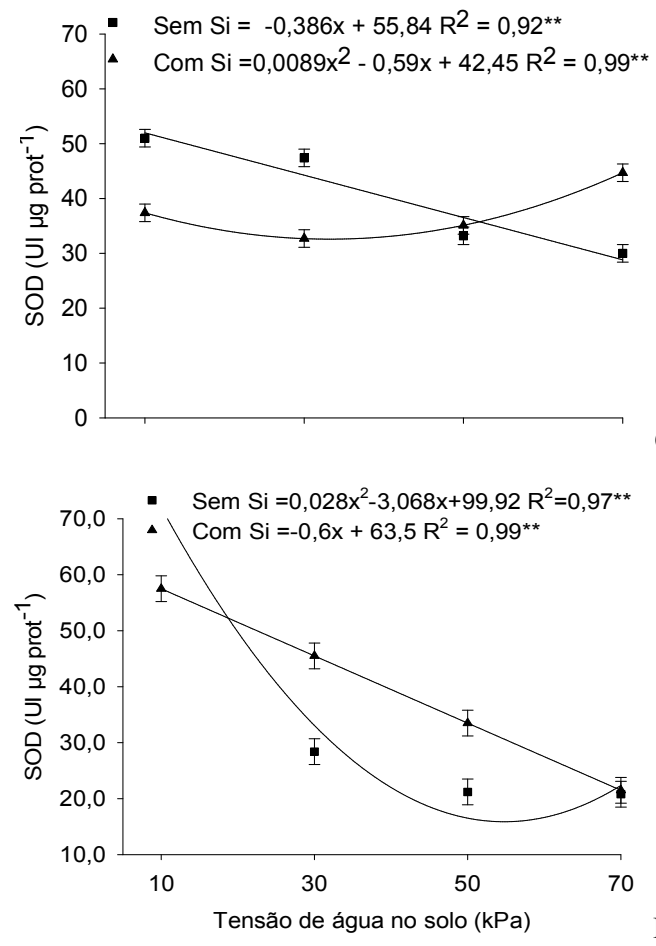

IAC 202

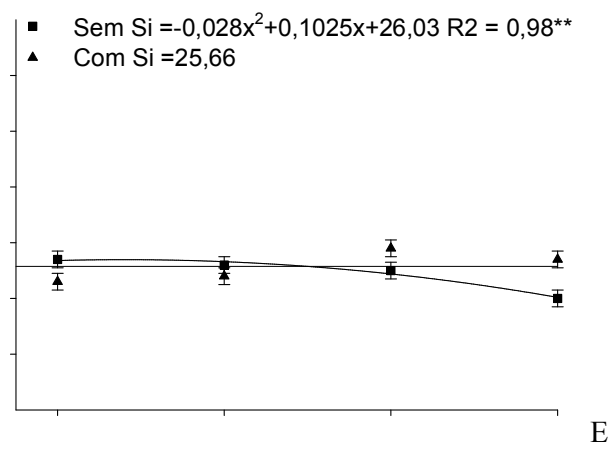

- Sem $\mathrm{Si}=0,0033 \mathrm{x}^{2}-0,4145 \mathrm{x}+29,349 \mathrm{R}^{2}=0,99^{\text {** }}$

- Com $\mathrm{Si}=21,25$

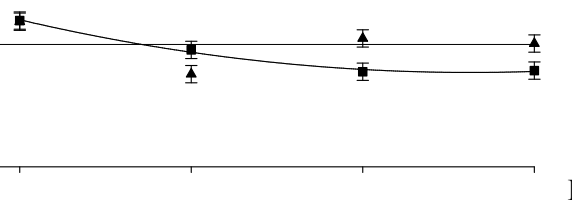

- $\operatorname{Sem} \mathrm{Si}=39,15$

- Com Si $=-0,0069 x^{2}+0,095 x+58,838 R^{2}=0,87^{* *}$

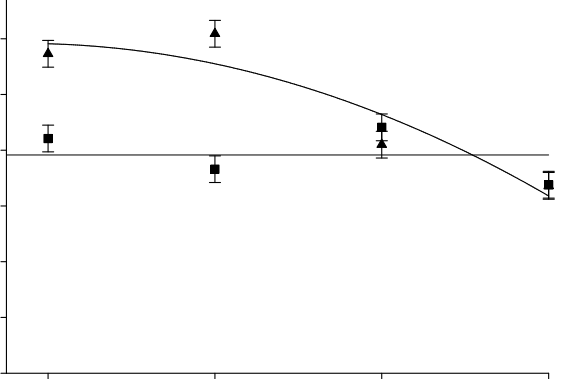

G

- Sem $S i=-0,3515 x+49,635 R^{2}=0,64^{* *}$

- Com Si $=-0,475 x+60,2 R^{2}=0,87^{* *}$

T
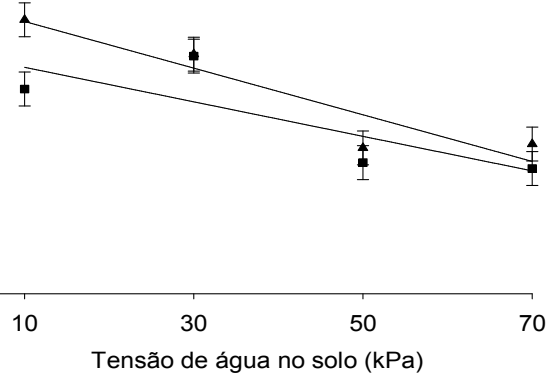

Fonte: Elaboração dos autores. 
Tabela 3. Análise da variância e coeficiente de variação para SOD em folhas de arroz cultivar Curinga e IAC 202, em função do manejo de água e silício, em quatro épocas de avaliação.

\begin{tabular}{|c|c|c|c|c|}
\hline \multirow{2}{*}{ Variáveis } & \multicolumn{4}{|c|}{ Fase fenológica } \\
\hline & Perfilhamento & Emborrachamento & Florescimento & Enchimento de grãos \\
\hline & \multicolumn{4}{|c|}{ Curinga } \\
\hline Corretivo $^{1}$ & ** & ** & $* *$ & $* *$ \\
\hline $\mathbf{k P a}^{2}$ & ns & $* *$ & $* *$ & $* *$ \\
\hline Corretivo*kPa & ns & $* *$ & $* *$ & $* *$ \\
\hline \multirow[t]{2}{*}{$\mathbf{C V}^{3}$} & 11 & 11 & 6 & 8 \\
\hline & \multicolumn{4}{|c|}{ IAC 202} \\
\hline Corretivo $^{1}$ & ns & ns & $* *$ & $* *$ \\
\hline $\mathbf{k P a}^{2}$ & ns & $* *$ & $* *$ & $* *$ \\
\hline Corretivo*kPa & ns & $\mathrm{ns}$ & $* *$ & $*$ \\
\hline $\mathrm{CV}^{3}$ & 14 & 10 & 7 & 12 \\
\hline
\end{tabular}

${ }^{1}$ Calcário e Silício; ${ }^{2}$ Tensão de água no solo; ${ }^{3}$ Coeficiente de variação; ns e ** e * = não significativo e significativo a $1 \%$ e $5 \%$ de probabilidade pelo teste $\mathrm{F}$, respectivamente.

Fonte: Elaboração dos autores.

Um aumento do nível da atividade de SOD sob condições de estresse pode resultar em uma maior eficiência na eliminação de ROS (WANGA et al., 2005). A terceira e quarta coleta (florescimento e enchimento de grãos) foram realizadas aos 40 e 54 dias após o estabelecimento da deficiência hídrica. Este período maior de restrição hídrica foi a provável razão pela qual não houve efeito da aplicação de Si, com maior deficiência hídrica. Outro aspecto que deve ser considerado é que as plantas estavam na fase reprodutiva e nesse estádio o comportamento enzimático pode ser alterado.

É importante destacar, que de maneira geral nos dois experimentos, a medida que se intensificou o estresse por deficiência hídrica houve redução da atividade da SOD. Outro ponto a ser destacado é que a atividade da SOD foi maior na terceira e quarta coleta em relação a primeira e a segunda. No entanto, embora os valores médios da SOD fossem maiores na terceira e quarta coleta, houve decréscimo quando a deficiência hídrica foi igual ou superior a $-50 \mathrm{kPa}$. Estes resultados demonstram que a partir de certo grau de deficiência hídrica o complexo enzimático de defesa da planta é prejudicado.

A enzima SOD age na dismutação de espécies reativas de oxigênio, comuns em situação de estresse ambiental. A formação destas espécies tende a se dividir de forma compartimentalizada nas células, conforme a intensidade da atividade. A enzima SOD apresenta aumento de atividade, sempre que as plantas são submetidas a um ambiente estressante, como salinidade, altas temperaturas, estresse hídrico, alta intensidade luminosa, ataque fitopatogênico e ou insetos (BROETTO; LUTTGE; RATAJCZAK, 2002).

Para a atividade da catalase a análise de variância (Tabela 4) mostrou-se significativa para a aplicação de corretivo (silício) em todas as coletas para o cultivar Curinga e na fase de florescimento para o cultivar IAC 202. Em relação as tensões de água no solo, somente na fase de emborrachamento não houve efeito para o cultivar Curinga, com a adição de silício (Figura 2B). Em condições maiores de deficiência hídrica de maneira geral a atividade da catalase foi reduzida (Figura 2), porém, observa-se comportamento de aumento da atividade da catalase com adição de silício na tensão de $-70 \mathrm{kPa}$ na fase de florescimento para o cultivar Curinga (Figura 2 C). Com a intensidade do estresse a catalase é susceptível e degrada-se, sendo fortemente dependente de um sistema contínuo de síntese (JALEEL et al., 2007). O maior nível de enzimas antioxidantes em plantas tratadas com silício parece criar condições de tolerância a este tipo de estresse. 
Figura 2. Atividade da catalase em folhas de arroz, cultivar Curinga e IAC 202 (A e E - perfilhamento, B e Femborrachamento, C e G- florescimento, D e H- enchimento de grãos), em função do manejo de água no solo e silício.

Curinga

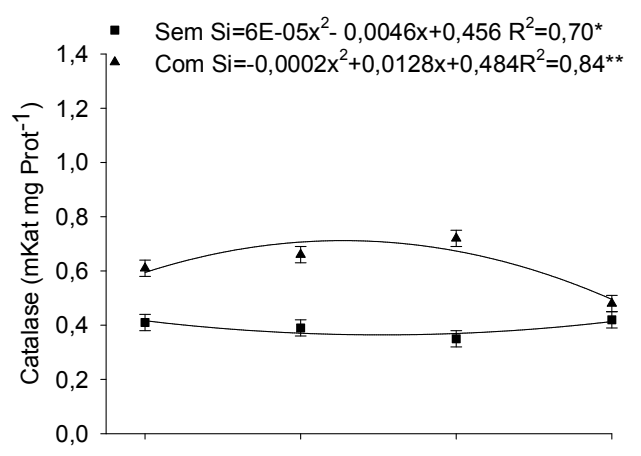

A
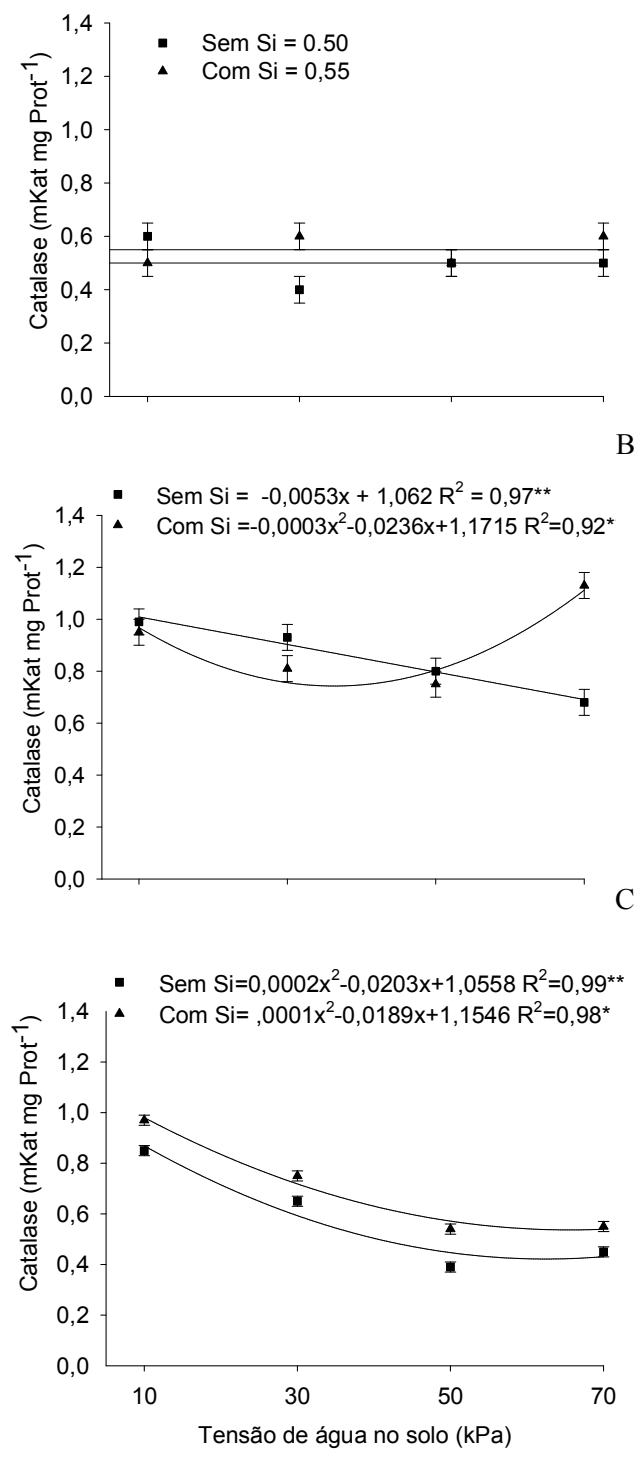

$\mathrm{D}$
IAC 202
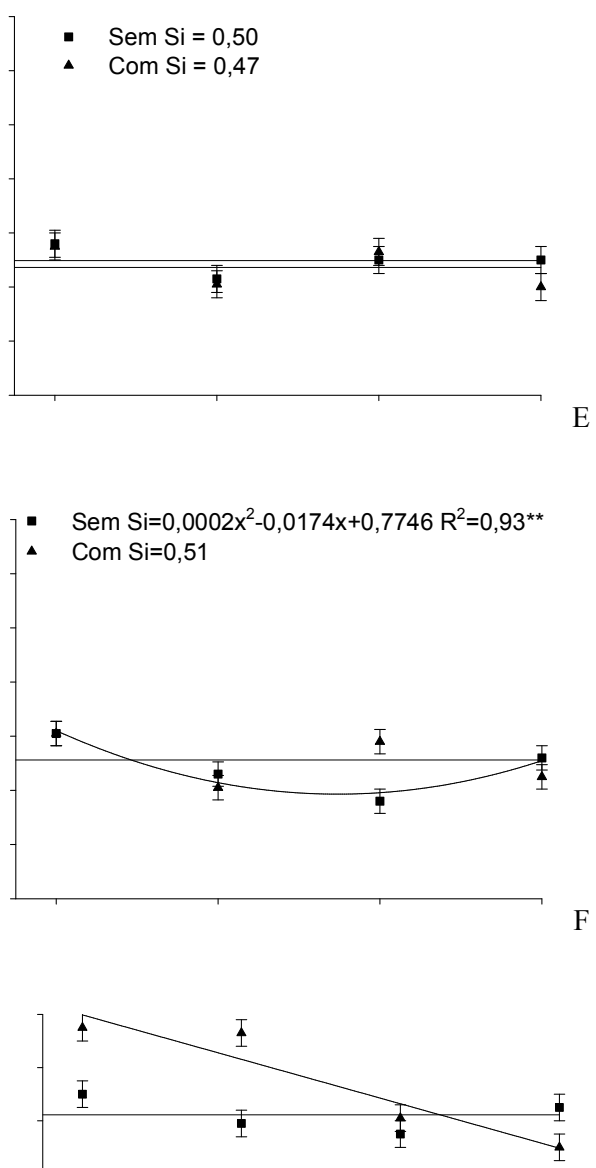

- $\quad$ Sem $\mathrm{Si}=0,50$

- Com $\mathrm{Si}=-0,0084 \mathrm{x}+1,4815 \mathrm{R}^{2}=0,90^{* *}$

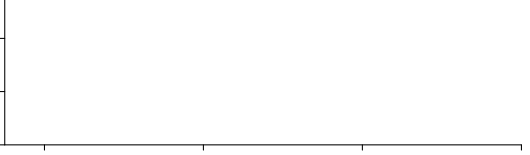

G

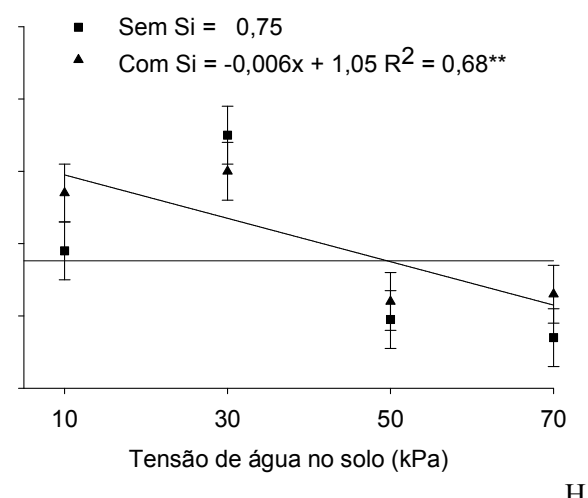

Fonte: Elaboração dos autores. 
Tabela 4. Análise da variância e coeficiente de variação para CAT em folhas de arroz cultivar Curinga e IAC 202, em função do manejo de água e silício, em quatro épocas de avaliação.

\begin{tabular}{|c|c|c|c|c|}
\hline \multirow{2}{*}{ Variáveis } & \multicolumn{4}{|c|}{ Fase fenológica } \\
\hline & Perfilhamento & Emborrachamento & Florescimento & Enchimento de grãos \\
\hline & \multicolumn{4}{|c|}{ Curinga } \\
\hline Corretivo $^{1}$ & ** & ** & * & ** \\
\hline $\mathbf{k P a}^{2}$ & ** & Ns & ** & ** \\
\hline Corretivo*kPa & ** & Ns & ** & * \\
\hline \multirow[t]{2}{*}{$\mathbf{C V}^{3}$} & 8 & 6 & 8 & 5 \\
\hline & \multicolumn{4}{|c|}{ IAC 202} \\
\hline Corretivo $^{1}$ & $\mathrm{~ns}$ & Ns & * & ns \\
\hline $\mathbf{k P a}^{2}$ & $* *$ & $* *$ & $* *$ & $* *$ \\
\hline Corretivo*kPa & ns & ** & $*$ & $*$ \\
\hline $\mathrm{CV}^{3}$ & 13 & 13 & 13 & 14 \\
\hline
\end{tabular}

${ }^{1}$ Calcário e Silício; ${ }^{2}$ Tensão de água no solo; ${ }^{3}$ Coeficiente de variação; ns e ** e * = não significativo e significativo a $1 \%$ e $5 \%$ de probabilidade pelo teste $\mathrm{F}$, respectivamente.

Fonte: Elaboração dos autores.

A redução na atividade da catalase indica que as plantas submetidas a estresse mais severo, $\mathrm{o}_{2} \mathrm{O}_{2}$ produzido pode ser mais consumido em processos oxidativos, como na peroxidação de lipídios, do que eliminado do metabolismo pela ação de enzimas antioxidantes.

Como estas reações elementares, ocorrem em nível de mitocôndrias e peroxissomos, postula-se que a atividade da catalase tenha acompanhado os eventos de dismutação de peróxido de hidrogênio, em cooperação com a enzima ascorbato peroxidase. Esta reação faz parte do ciclo água-água, cuja reação básica de dismutação de radicais livres, foi desencadeada pela SOD (SFALCIN, 2009).

A atividade da APX de acordo com a análise de variância não foi influenciada pelos corretivos de solo (Tabela 5). Quanto as tensões de água no solo para o cultivar Curinga os efeitos ocorreram no florescimento, para as tensões $-10 \mathrm{e}-30 \mathrm{kPa}$ (Figura 3C) e para o cultivar IAC 202 houve ajuste linear com queda da atividade com o aumento das tensões de água durante a fase de enchimento de grãos (Figura $3 \mathrm{H}$ ).

A atuação maior dessa enzima nesses estádios pode indicar um maior potencial de remoção de $\mathrm{H}_{2} \mathrm{O}_{2}$ no interior das células. Um maior consumo de $\mathrm{H}_{2} \mathrm{O}_{2}$ deve estar contribuindo para menor formação do radical hidroxila e, assim, reduzir os danos causados no metabolismo deste cultivar. Nas coletas realizadas no florescimento e enchimento de grãos (Figura 3 D, H), observou-se tendência de redução da atividade enzimática quando a restrição de água no solo foi mais severa.

Tabela 5. Análise da variância e coeficiente de variação para APX em folhas de arroz cultivar Curinga e IAC 202, em função do manejo de água e silício, em quatro épocas de avaliação.

\begin{tabular}{|c|c|c|c|c|}
\hline \multirow{2}{*}{ Variáveis } & \multicolumn{4}{|c|}{$\begin{array}{c}\text { Fase fenológica } \\
\end{array}$} \\
\hline & Perfilhamento & Emborrachamento & Florescimento & Enchimento de grãos \\
\hline & \multicolumn{4}{|c|}{ Curinga } \\
\hline Corretivo $^{1}$ & ns & Ns & ns & ** \\
\hline $\mathbf{k P a}^{2}$ & ns & Ns & ** & ** \\
\hline Corretivo*kPa & ns & Ns & ns & ** \\
\hline \multirow[t]{2}{*}{$\mathbf{C V}^{3}$} & 13 & 19 & 12 & 13 \\
\hline & \multicolumn{4}{|c|}{ IAC 202} \\
\hline Corretivo $^{1}$ & ns & Ns & ns & ns \\
\hline $\mathbf{k P a}^{2}$ & ns & Ns & ns & * \\
\hline Corretivo*kPa & ns & $*$ & ns & ns \\
\hline $\mathrm{CV}^{3}$ & 25 & 23 & 25 & 34 \\
\hline
\end{tabular}

${ }^{1}$ Calcário e Silício; ${ }^{2}$ Tensão de água no solo; ${ }^{3}$ Coeficiente de variação; ns e ** e * = não significativo e significativo a $1 \%$ e $5 \%$ de probabilidade pelo teste $\mathrm{F}$, respectivamente.

Fonte: Elaboração dos autores. 
Figura 3. Atividade da APx em folhas de arroz, cultivar Curinga e IAC 202 (A e E - perfilhamento, B e Femborrachamento, C e G- florescimento, D e H- enchimento de grãos), em função do manejo de água no solo e silício.

Curinga

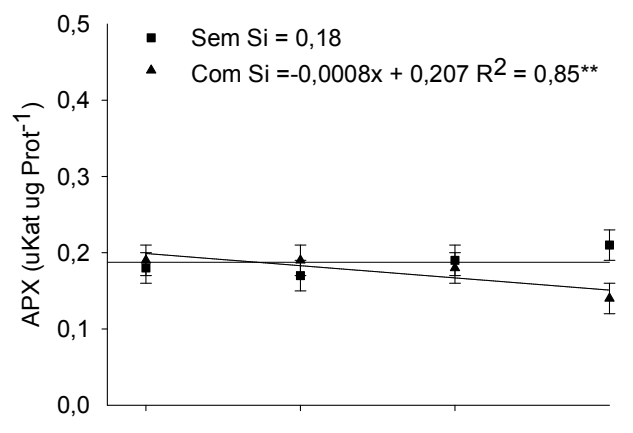

A
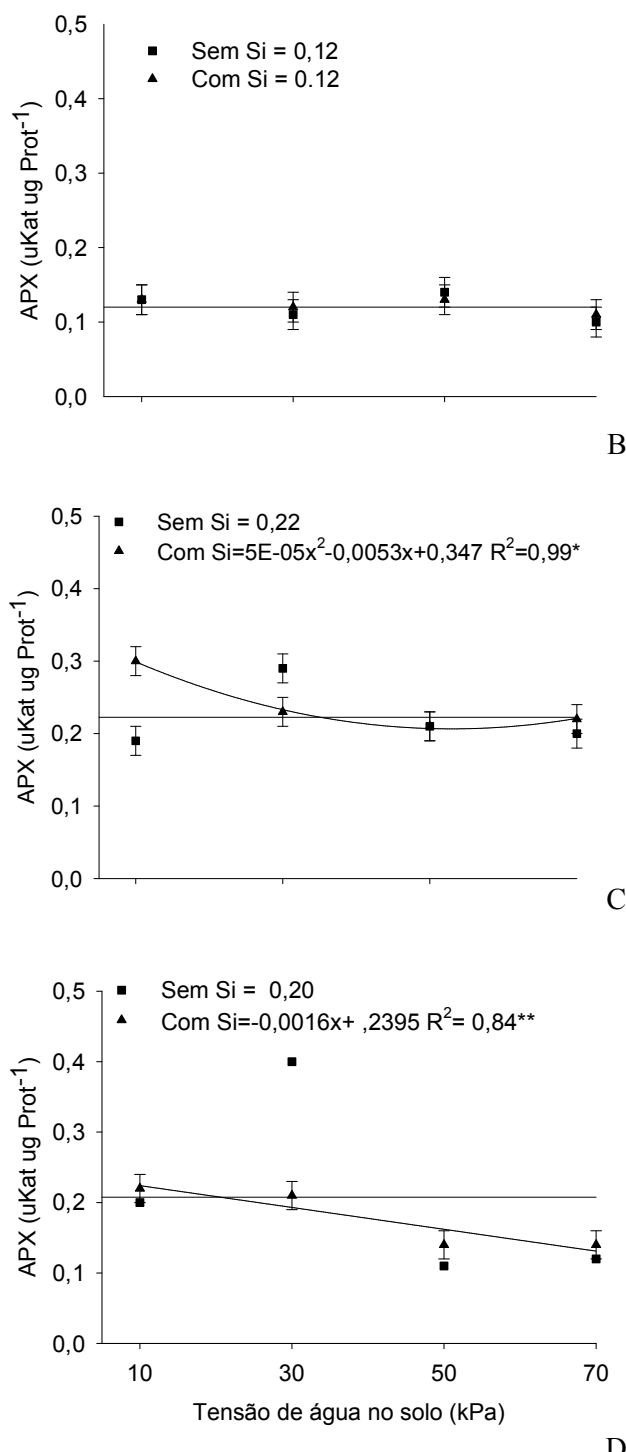

IAC 202

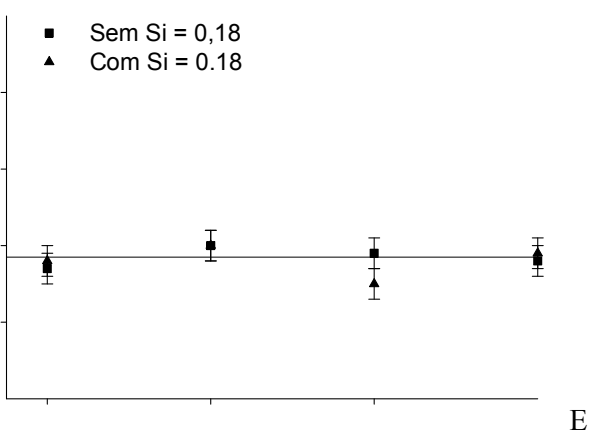

- $\operatorname{Sem} \mathrm{Si}=0,13$

- Com $\mathrm{Si}=0,13$

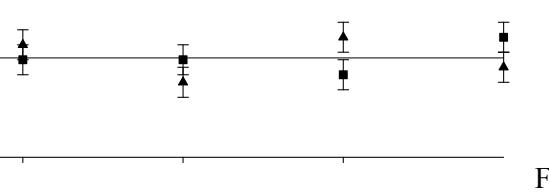

- $\operatorname{Sem} \mathrm{Si}=0,26$

- Com $\mathrm{Si}=0,26$

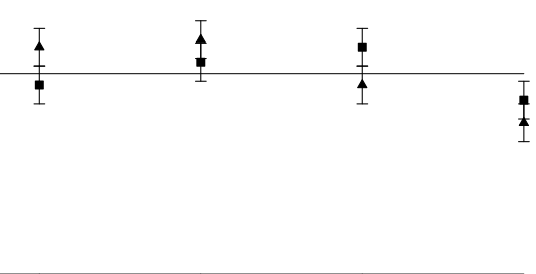

G

- $\operatorname{Sem} \mathrm{Si}=0,18$

- Com $\mathrm{Si}=-0,0021 \mathrm{x}+0,3045 \mathrm{R}^{2}=0,94^{\star *}$

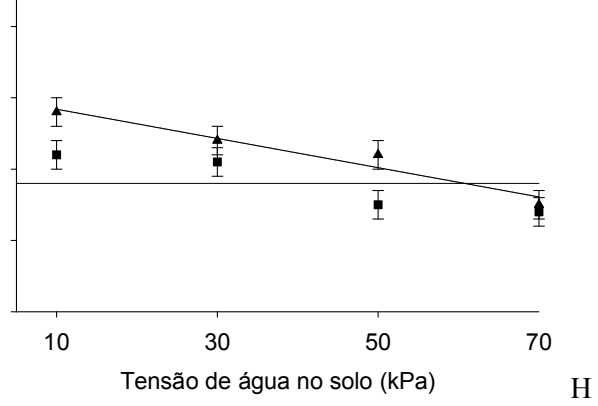

Fonte: Elaboração dos autores. 
Balakhnina e Borkowska (2013) afirmam que a atividade enzimática de CAT, SOD e APx aumentam como resposta a estresses ambientes, sendo que a Apx pode exercer função mais extensiva de regulação do metabolismo. O sistema antioxidativo enzimático é desencadeado por sucessões de enzimas ligadas no combate a radicais oxidativos a célula. Os resultados revelam uma diminuição dessa atividade em determinados momentos podendo estar relacionado a uma maior concentração de ROS em relação a enzimas antioxidativas. Ribeiro (2007) observou decréscimo na atividade da APX em folhas de arroz estressadas com alumínio. As enzimas CAT e APX utilizam como substrato o $\mathrm{H}_{2} \mathrm{O}_{2}$, sendo a APX (em nível de $\mu \mathrm{M}$ ) e a CAT (a nível de $\mathrm{mM}$ ). A diferença funcional entre as duas é que a APX parece ser responsável pela modulação fina da ERO, enquanto a CAT deve exercer papel de remoção de $\mathrm{H}_{2} \mathrm{O}_{2}$ durante o estresse (ROSA, 2008).
Os dados referentes à taxa liquida de assimilação de $\mathrm{CO}_{2}$ para cultivar Curinga foi alterada pela presença ou ausência do Si (Tabela 6). Para ambos os cultivares na coleta em fase de florescimento ocorreu uma diminuição na taxa de assimilação de $\mathrm{CO}_{2}$ mais acentuada (Figura $4 \mathrm{C} ; \mathrm{F}$ ). No cultivar IAC 202 houve diferença entre a adubação com silício e as plantas sem o corretivo na fase de perfilhamento e emborrachamento com tensão de $-50 \mathrm{kPa}$ (Figura $4 \mathrm{D}$; E), e nas tensões -10 e $-30 \mathrm{kPa}$ na fase de florescimento (Figura 4F). Em todas as coletas a taxa de assimilação de $\mathrm{CO}_{2}$ foi diminuindo com as maiores tensões de água, a intensificação da falta de água prejudica os mecanismos de relações hídricas (Figura 4).

Tabela 6. Análise da variância e coeficiente de variação para Taxa de assimilação de $\mathrm{CO} 2$ em folhas de arroz cultivar Curinga e IAC 202, em função do manejo de água e silício, em três épocas de avaliação.

\begin{tabular}{|c|c|c|c|}
\hline \multirow{2}{*}{ Variáveis } & \multicolumn{3}{|c|}{ Fase fenológica } \\
\hline & Perfilhamento & Emborrachamento & Florescimento \\
\hline & \multicolumn{3}{|c|}{ Curinga } \\
\hline Corretivo $^{1}$ & $* *$ & $* *$ & ** \\
\hline $\mathbf{k P a}^{2}$ & $* *$ & $* *$ & $* *$ \\
\hline Corretivo*kPa & $* *$ & $* *$ & $* *$ \\
\hline \multirow[t]{2}{*}{$\mathrm{CV}^{3}$} & 6 & 8 & 10 \\
\hline & \multicolumn{3}{|c|}{ IAC 202} \\
\hline Corretivo $^{1}$ & Ns & ns & $* *$ \\
\hline $\mathbf{k P a}^{2}$ & $* *$ & $* *$ & $* *$ \\
\hline Corretivo*kPa & $* *$ & $* *$ & $* *$ \\
\hline $\mathrm{CV}^{3}$ & 8 & 6 & 5 \\
\hline
\end{tabular}

${ }^{1}$ Calcário e Silício; ${ }^{2}$ Tensão de água no solo; ${ }^{3}$ Coeficiente de variação; ns e ** e * = não significativo e significativo a $1 \%$ e $5 \%$ de probabilidade pelo teste $\mathrm{F}$, respectivamente.

Fonte: Elaboração dos autores. 
Figura 4. Taxa de assimilação de $\mathrm{CO}_{2}(A)$ em folhas de arroz, cultivar Curinga e IAC 202 (A e D - perfilhamento, B e E- emborrachamento, C e F- florescimento), em função do manejo de água no solo e silício.

\section{Curinga}

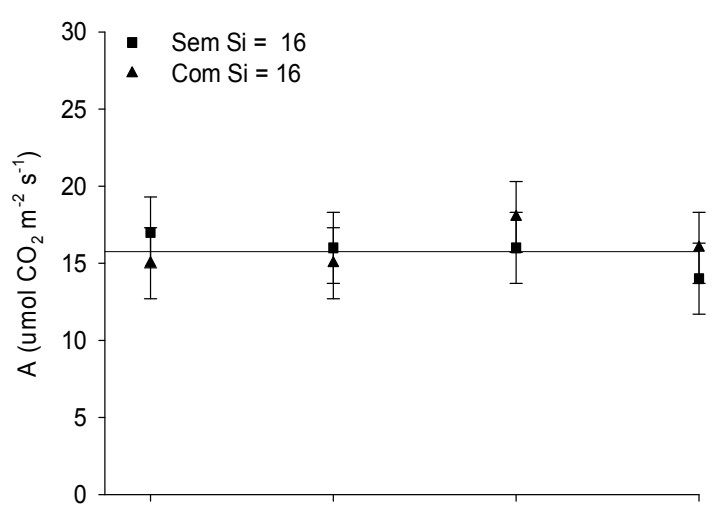

A

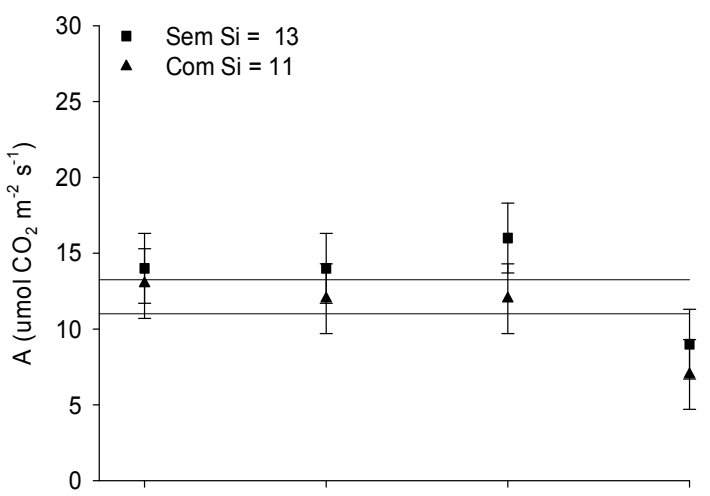

B

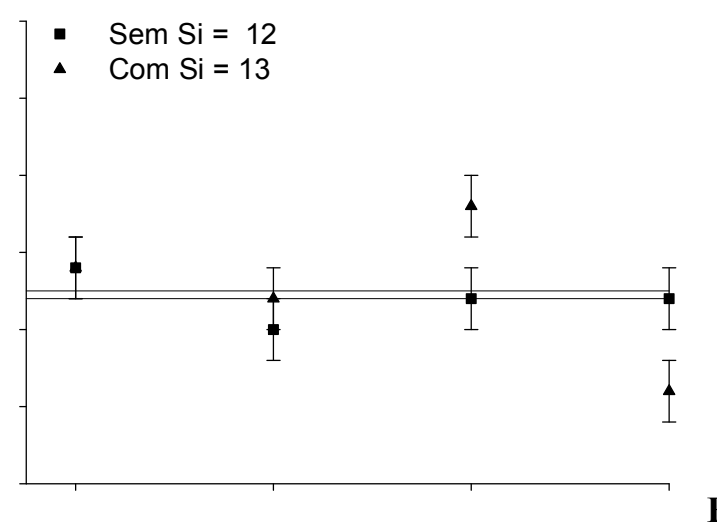

IAC 202

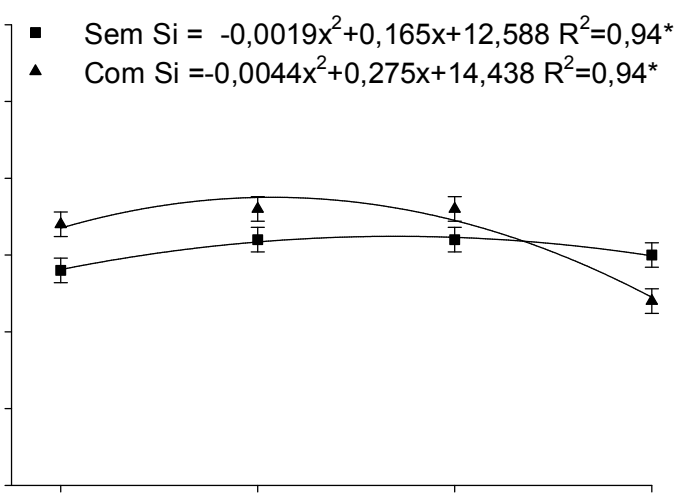

D
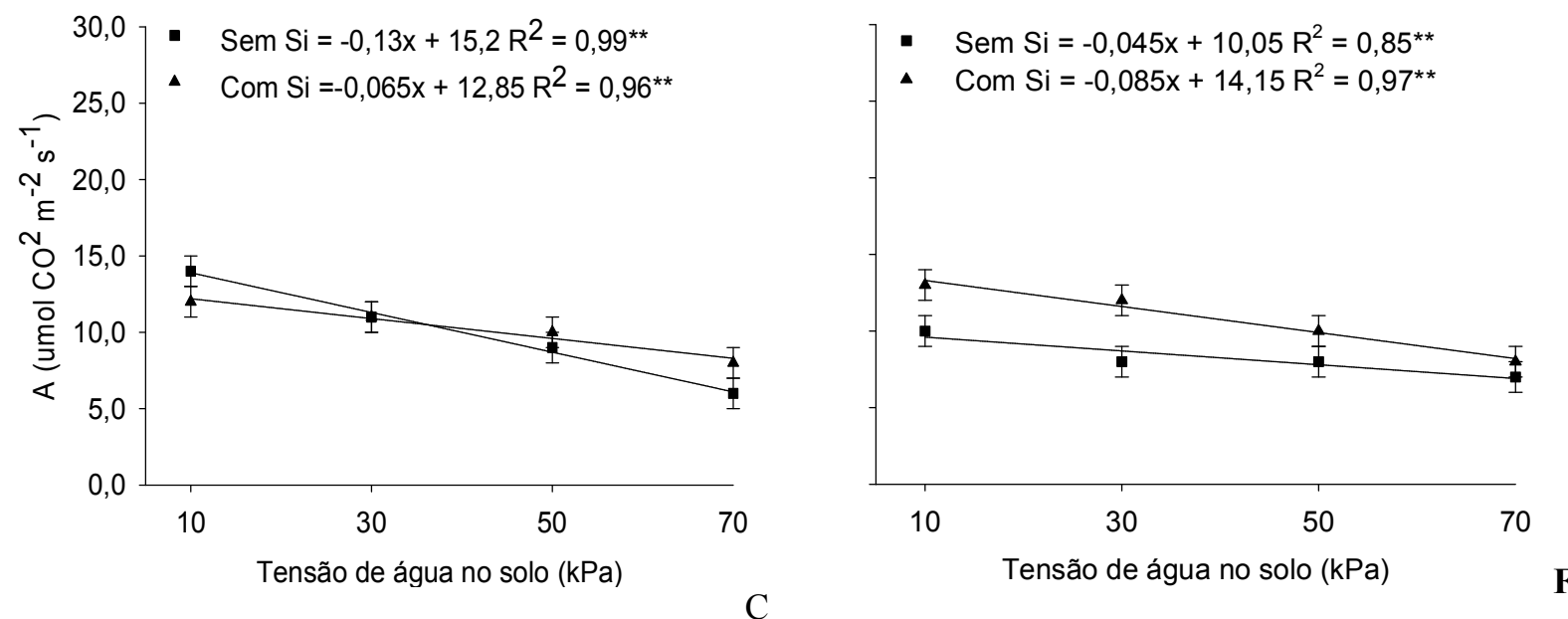

Fonte: Elaboração dos autores. 
Observa-se diminuição significativa entre o tratamento controle e a maior tensão de água durante a fase de florescimento (Figura $4 \mathrm{C}$; F) com a redução da assimilação de $\mathrm{CO}_{2}$ em ambos os cultivares, e para ambos os tratamentos. Com o aumento da deficiência hídrica as plantas tendem a fechar os estômatos acarretando a diminuição da fotossíntese (CHAVES; FLEXAS; PINHEIRO, 2009).

A redução da taxa fotossintética pode ocorrer por fatores estomáticos e não-estomáticos (de origem bioquímica e fotoquímica). Podendo haver uma baixa regulação do aparato fotoquímico e bioquímico se a disponibilidade de $\mathrm{CO}_{2}$ é o componente mais limitante para a fotossíntese em plantas sob deficiência hídrica (FLEXAS et al., 2009). Quando os estômatos estão fechados, se estabelece nas plantas certa resistência à perda de água, com reflexos sobre as atividades metabólicas, devido à redução da difusão do $\mathrm{CO}_{2}$ para o mesofilo e menor rendimento quântico do fotossistema II (CHAVES et al., 2010).

O fotossistema II depende da água para a geração de energia química, requerida posteriormente para a fixação de $\mathrm{CO}_{2}$, variações na disponibilidade hídrica geram menor eficiência do fotossistema II, ou seja, com recurso de água limitado, menos ATP e NADPH são formados e, como consequência, menos $\mathrm{CO}_{2}$ é fixado. Esses resultados corroboram com os de Liang et al. (2007) que estudando arroz em condição de estresse também verificaram aumento da taxa assimilação de $\mathrm{CO}_{2}$ com a aplicação de silício.

Os resultados da adubação silicatada em plantas submetidas a restrição hídrica demonstraram uma queda da atividade enzimática e na taxa liquida de assimilação de $\mathrm{CO}_{2}$ em deficiências hídricas mais intensas e ao longo do tempo fenológico das mesmas. Porém, a aplicação de silício melhorou a atividade enzimática contra as possíveis ROS e amenizou os efeitos da seca sobre a taxa fotossintética.

A produção de grãos foi influenciada pelos corretivos e pelas tensões de água em ambos os cultivares (Tabela 7), como demonstra a análise de variância. De maneira geral a medida que a restrição de água foi intensificada houve redução na produção de grãos (Figura 5). A exceção foi o cultivar Curinga (Figura 5A), cuja produção não foi reduzida a medida que a deficiência hídrica foi maior, quando o corretivo utilizado foi o silicato de cálcio. Isto pode ter ocorrido por este cultivar ser mais eficiente no uso da água principalmente quando há adição de silício.

Tabela 7. Análise da variância e coeficiente de variação para produção de grãos dos cultivar Curinga e IAC 202, em função do manejo de água e silício.

\begin{tabular}{lcc}
\hline \multicolumn{1}{c}{ Variáveis } & \multicolumn{2}{c}{ Cultivar } \\
\cline { 2 - 3 } Corretivo $^{1}$ & Curinga & IAC 202 \\
kPa $^{2}$ & $* *$ & $* *$ \\
Corretivo $^{*} \mathbf{k P a}$ & $*$ & $* *$ \\
$\mathbf{C V}^{3}$ & $*$ & $* *$ \\
\hline
\end{tabular}

${ }^{1}$ Calcário e Silício; ${ }^{2}$ Tensão de água no solo; ${ }^{3}$ Coeficiente de variação; ns e ** = não significativo e significativo $1 \%$ de probabilidade pelo teste $\mathrm{F}$, respectivamente.

Fonte: Elaboração dos autores.

A produção de grãos para o IAC 202 (Figura $5 \mathrm{~B})$, aumentou com adição de silício até a tensão de $-50 \mathrm{kPa}$. Ambos cultivares apresentaram acréscimo de produção na presença de silício, principalmente quando aumentava as tensões de água, assim como ocorreu nas taxas de assimilação de $\mathrm{CO}_{2}$ (Figura 4 $\mathrm{C}$; F), demonstrando assim que a relação entre os dois parâmetros foi favorecida com a aplicação de 
silício, mesmo em condição de deficiência hídrica. Crusciol et al. (2003), afirma que o arroz cultivado no sistema de sequeiro apresenta, em geral, além da baixa produtividade, qualidade de grão inferior quando comparado com o grão oriundo de cultura irrigada por inundação. A maior causa desse problema, além dos atribuídos à genética do material, está relacionada com os frequentes períodos de deficiência hídrica que a planta sofre durante o ciclo. Experimentos de deficiência hídrica realizados por Ramos et al. (2012) utilizando o cultivar AN Cambará, demonstraram que a adição de silício proporcionou maior produção de grãos, quando comparados as plantas que não receberam o silício. Esses resultados indicam que sob algum tipo de estresse a adequada nutrição com silício ameniza a intensidade de redução da produção de grãos, acarretando diferenças significativas às plantas que não receberam silício.

Figura 5. Produção de arroz cultivar Curinga (A) e IAC 202 (B), em função do manejo de água e silício.

\section{Curinga}

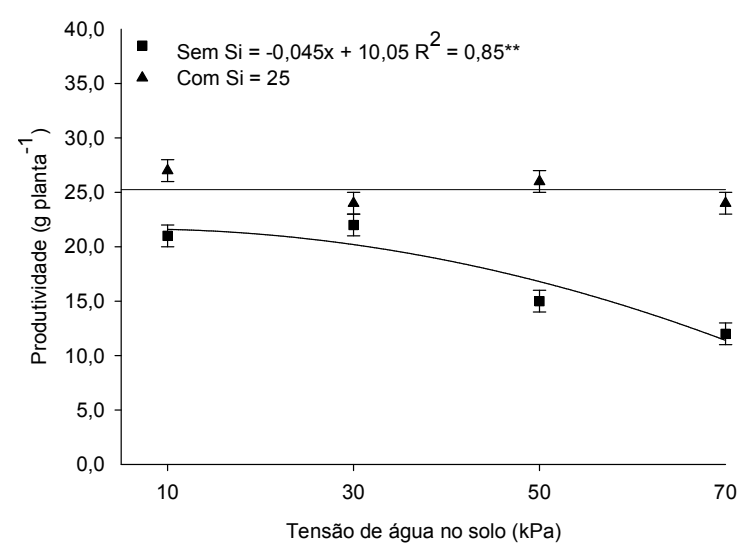

A
IAC 202

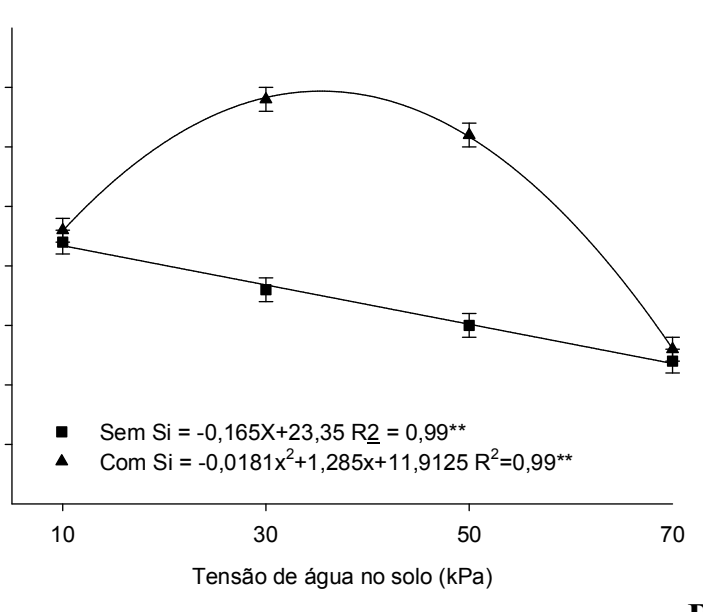

B

Fonte: Elaboração dos autores.

\section{Conclusões}

A atividade enzimática aumenta com a aplicação de silício mesmo em condições de deficiência hídrica mais intensa. A taxa de assimilação de $\mathrm{CO}_{2}$ e a produção de grãos também aumentam com a adição de silício. A aplicação de silício em ambos os cultivares de arroz ameniza os efeitos do estresse ocasionado pela deficiência hídrica.

\section{Agradecimento}

À CAPES pela concessão de bolsa de estudo a primeira autora.

\section{Referências}

ANJUM, S. A.; XIE, X.; WAN, L. C.; SALEEM, M. F.; MAN, C.; LEI, W. Morphological, physiological and biochemical responses of plants to drought stress. African Journal of Agricultural Research, Nigéria, v. 6, n. 9 , p. 2026-2032, 2011. 
BALAKHNINA, T.; BORKOWSKA, A. Effects of silicon on plant resistance to environmental stresses: review. International Agrophysics, Lublin, v. 27, n. 2, p. 225-232, 2013.

BROETTO, F.; LUTTGE, U.; RATAJCZAK, R. Influence of ligth intensity and salt treatment on mode of photosyntesis and enzymes of the antioxidatives response system of Mesembryanthemum crystallium. Functional Plant Biology, Victoria, v. 29, n. 1, p. 13-23, 2002.

CARVALHO, F. E. L.; RIBEIRO, C. W.; MARTINS, M. O.; BONIFACIO, A.; STASTSC, C. C.; ANDRADE, C. M. B.; CERQUEIRA, J. V.; PINHEIRO, M. M.; SILVEIRA, J. A. G. Cytosolic APX knockdown rice plants sustain photosynthesis by regulation of protein expression related to photochemistry, Calvin cycle and photorespiration. Physiologia Plantarum, Blacksburg, v. 150, n. 4, p. 632-645, 2014.

CHAVES, M. M.; ZARROUK, O.; FRANCISCO, R.; COSTA, J. M.; SANTOS, T.; REGALADO, A. P.; RODRIGUES, M. L.; LOPES, C. M. Grapevine under deficit irrigation: hints from physiological and molecular data. Annals of Botany, Oxford, v. 105, n. 5, p. 661-676, 2010.

CHAVES, M. M.; FLEXAS, J.; PINHEIRO, C. Photosynthesis under drought and salt Stress: Regulation mechanisms from whole plant to cell. Annals of Botany, Oxford, v. 103, n. 4, p. 551-560, 2009.

CRUSCIOL, C. A. C.; ARF, O.; SORATTO, R. P.; ANDREOTTI, M. Produtividade do arroz de terras altas sob condições de sequeiro e irrigado por aspersão em função do espaçamento entre fileiras. Agronomia, Botucatu, v. 37, n. 1, p. 10-15, 2003.

EMPRESA BRASILEIRA DE PESQUISA AGROPECUÁRIA - EMBRAPA. Manual de métodos de análise de solo. Rio de Janeiro: CNPS, 1997. 212 p.

FLEXAS, J.; BARON, M.; BOTA, J.; DUCRUET, J. M.; GALLÉ, A.; JIMÉNEZ, M.; POU, A.; CARBÓ, M. R.; SAJNANI, C.; TÓMAS, M.; MEDRANO, H. Photosynthesis limitations during water stress acclimation and recovery in the drought-adapted Vitis hybrid Richter-110 ( $V$. berlandieri $\mathrm{x} V$. rupestris). Journal of Experimental Botany, Oxford, v. 60, n. 8, p. 2362-2377, 2009.

GARA, L. de; LOCATO V.; DIPIERRO S.; PINTO M. C. de. Redox homeostasis in plants. The challenge of living with endogenous oxygen production. Respiratory Physiology and Neurobiology, Victoria, v. 173, n. 31, p. 13-19. 2010.

GIANNOPOLITIS, C. N.; RIES, S. K. Supeóxido dismutases. I. occurrence in higher plants. Plant
Physiology, Illinois, v. 59, n. 2, p. 309-314, 1977.

GILL, S. S.; TUJELA, N. Reactive oxygen species and antioxidant machinery in abiotic stress tolerance in crop plants. Plant Physiology and Biochemistry, Amsterdam, v. 48, n. 12, p. 909-930, 2010.

JALEEL, C. A.; MANIVANNAN, P.; SANKAR, B.; KISHOREKUMAR, A.; GOPI, R.; SOMASUNDARAM, R.; PANNEERSELVAM, R. Water deficit stress mitigation by calcium chloride in Catharanthus roseus: effects on oxidative stress, praline metabolism and indole alkaloid accumulation. Colloids and Surfaces B: Biointerfaces, Amsterdam, v. 60, n. 1, p. 110-116, 2007.

JONES, H. G.; OSMOND, C. B. Photosynthesis by thin leaf slices in solution. I Properties of leaf slices and comparison with whole leaves. Journal Bioscience Science, Canberra, v. 26, n. 1, p. 15-24, 1973.

KLUTHCOUSKI, J.; PINHEIRO, B. S. Cultivo do arroz de terras altas. Embrapa Arroz e Feijão. Sistemas de Produção. Brasília, 2003. Disponível em: <http:// sistemasdeproducao.cnptia.embrapa.br/FontesHTML/ Arroz/ArrozTerrasAltas/importancia.htm>. Acesso em: 08 jul. 2013.

KOSHIBA, T. Cytosolic ascorbate peroxidase in seedlings and leaves of maize (Zea mays). Plant and Cell Physiology, Kioto, v. 34, p.713-721, 1993.

LIANG, Y. C.; SUN, W. C.; ZHU, Y. G.; CHRISTIE, P. Mechanisms of silicon-mediated alleviation of abiotic stresses in higher plants: a review. Environmental Pollution, Berlin, v. 147, n. 2, p. 422-428, 2007.

MAUAD, M.; CRUSCIOL, C. A. C.; GRASSI FILHO, H. Produção de massa seca e nutrição de cultivares de arroz de terras altas sob condição de déficit hídrico e adubação silicatada. Semina: Ciências Agrárias, Londrina, v. 32, n. 3, p. 939-948, 2011.

MOLDES, C. A.; BATISTA, G. B.; FONTÃO-FILHO, O.; AZEVEDO, R. A.; TSAI, S. M. Actividad de enzimas antioxidantes em algodón com diferentes dosis de silicio. In: REUNIÓN DE LA ASOCIACIÓN ARGENTINA DE FISIOLOGÍA VEGETAL, 26., 2006, Chascomus. Anais... Chascomus: AAFV: Asociación Argentina de Fisiología Vegetal, 2006.

NWUGO, C. C.; HUERTA, A. J. Effects of silicon nutrition on cadmium uptake, growth and photosynthesis of rice plants exposed to low-level cadmium. Plant and Soil, Dordrecht, v. 311, n. 1, p. 73-86, 2008.

OLIVEIRA, L. A.; KORNDÖRFER, G. H.; PEREIRA, A. C. Acumulação de silício em arroz em diferentes condições de $\mathrm{pH}$ da rizosfera. Revista Brasileira de Ciência do Solo, Viçosa, MG, v. 31, n. 4, p. 685-690, 2007. 
PEAK, D. Evidence for complex, collective dynamics and emergent, distributed computation in plants. Proceedings of the National Academy of Sciences of the United States of America, Washington, v. 101, n. 4, p. 918-922, 2004.

PEIXOTO, P. H. P.; CAMBRAIA, J.; SANT'ANNA, R.; MOSQUIM, P. R.; MOREIRA, M. A. Aluminum effects on lipid peroxidation and the activities of enzymes of oxidative metabolism in sorghum. Revista Brasileira de Fisiologia Vegetal, Viçosa, MG, v. 11, n. 3, p. 137-143, 1999.

PULZ, A. L. Estresse hídrico e adubação silicatada em batata (Solanum Tuberosun L.) c.v. Bintje. 2007. Dissertação (Mestrado em Agronomia/Agricultura) - Faculdade de Ciências Agronômicas. Universidade Estadual Paulista, Botucatu.

RAIJ, B.; ANDRADE, J. C.; CANTARELLA, H.; QUAGGIO, J. A. Análise química para avaliação da fertilidade de solos tropicais. Campinas: Instituto Agronômico, 2001. 284 p.

RAMOS, D. T.; LUZ, P. B.; MACHADO, M. D.; CASSIOLATO, M. E.; SOBRINHO, S. P.; NEVES, L. G. Influência da adubação silicatada na produção de arroz de sequeiro. Revista Brasileira de Ciências Agrárias, Recife, v. 7, n. 4, p. 543-547, 2012.

REDDY,A.R.; CHAITANYA,K.V.; VIVEKANANDAN, M. Drought-induced responses of photosynthesis and antioxidant metabolism in higher plants. Journal of Plant Physiology, Stuttgart, v. 161, n. 11, p. 1189-1202, 2004.

RIBEIRO, C. Sistema de defesa contra estresses oxidativos em dois cultivares de arroz (Oryza sativa L.) com tolerância diferencial ao alumínio. 2007. Dissertação (Mestrado em Fisiologia Vegetal) - Universidade Federal de Viçosa, Viçosa, MG.
RICHARDS, L. A. Methods of measuring moisture tension. Soil Science, Nova Jérsei, v. 68, n. 1, p. 95-112, 1949.

ROSA, S. B. Caracterização funcional das isoformas citosólicas e peroxissomais de ascorbato peroxidase em arroz. 2008. Dissertação (Mestrado em Biologia Celular e Molecular) - Centro de Biotecnologia. Universidade Federal do Rio Grande do Sul, Porto Alegre.

SFALCIN, R. A. Avaliação de parâmetros fisiológicos e bioquímicos em berinjela (solanum melongena l.) cultivada sob diferentes potenciais de água no solo. 2009. Dissertação (Mestrado em Agronima/Energia na Agricultura) - Universidade Estadual Paulista, Botucatu.

SOARES, L. C. S.; RAPHAEL, J. P. A.; BORTOLOTTO, R. P.; NORA, D. D.; GRUHN, E. M. Blast disease in rice culture. Brazilian Journal of Applied Technology for Agricultural Science, Guarapuava, v. 7, n. 2, p. 109-119, 2014.

TOPP, G. C.; GALGANOV,Y.T.; BALL, B. C.; CARTER, M. R. Soil water desorption curves. In: CARTER, M. R. (Ed.). Soil sampling and methods of analysis. Florida: Lewis Publishers, 1993. p. 569-579.

WANGA, F. Z.; WANGA, Q. B.; KWOND, S. Y.; KWAKB, S. S.; SUA, W. A. Enhanced drought tolerance of transgenic rice plant $\mathrm{s}$ expressing a pea manganese superoxide Dismutase. Journal of Plant Physiology, Stuttgart, v. 162, n. 4, p. 465-472, 2005. 